\title{
Suitability of modelled and remotely sensed essential climate variables for monitoring Euro-Mediterranean droughts
}

\author{
C. Szczypta ${ }^{1, *}$, J.-C. Calvet ${ }^{1}$, F. Maignan ${ }^{2}$, W. Dorigo ${ }^{3}$, F. Baret $^{4}$, and P. Ciais ${ }^{2}$ \\ ${ }^{1}$ CNRM-GAME, UMR3589 (Météo-France, CNRS), Toulouse, France \\ ${ }^{2}$ Laboratoire des Sciences du Climat et de l'Environnement, IPSL, CEA/CNRS/UVSQ - UMR8212, Gif-sur-Yvette, France \\ ${ }^{3}$ Department of Geodesy and Geoinformation, Vienna University of Technology, Vienna, Austria \\ ${ }^{4}$ INRA, EMMAH - UMR1114, Avignon, France \\ *now at: CESBIO, UMR 5126 (CNES, CNRS, IRD, UPS), Toulouse, France
}

Correspondence to: J.-C. Calvet (jean-christophe.calvet@meteo.fr)

Received: 2 October 2013 - Published in Geosci. Model Dev. Discuss.: 6 November 2013

Revised: 10 March 2014 - Accepted: 7 April 2014 - Published: 20 May 2014

\begin{abstract}
Two new remotely sensed leaf area index (LAI) and surface soil moisture (SSM) satellite-derived products are compared with two sets of simulations of the ORganizing Carbon and Hydrology In Dynamic EcosystEms (ORCHIDEE) and Interactions between Soil, Biosphere and Atmosphere, $\mathrm{CO}_{2}$-reactive (ISBA-A-gs) land surface models. We analyse the interannual variability over the period 19912008. The leaf onset and the length of the vegetation growing period (LGP) are derived from both the satellite-derived LAI and modelled LAI. The LGP values produced by the photosynthesis-driven phenology model of ISBA-A-gs are closer to the satellite-derived LAI and LGP than those produced by ORCHIDEE. In the latter, the phenology is based on a growing degree day model for leaf onset, and on both climatic conditions and leaf life span for senescence. Further, the interannual variability of LAI is better captured by ISBAA-gs than by ORCHIDEE. In order to investigate how recent droughts affected vegetation over the Euro-Mediterranean area, a case study addressing the summer 2003 drought is presented. It shows a relatively good agreement of the modelled LAI anomalies with the observations, but the two models underestimate plant regrowth in the autumn. A better representation of the root-zone soil moisture profile could improve the simulations of both models. The satellite-derived SSM is compared with SSM simulations of ISBA-A-gs only, as ORCHIDEE has no explicit representation of SSM. Overall, the ISBA-A-gs simulations of SSM agree well with the satellite-derived SSM and are used to detect regions where the satellite-derived product could be improved. Finally, a
\end{abstract}

correspondence is found between the interannual variability of detrended SSM and LAI. The predictability of LAI is less pronounced using remote sensing observations than using simulated variables. However, consistent results are found in July for the croplands of the Ukraine and southern Russia.

\section{Introduction}

The Global Climate Observing System (GCOS) has defined a list of atmospheric, oceanic and terrestrial essential climate variables (ECVs) which can be monitored at a global scale from satellites. Terrestrial ECV products consisting of long time series are needed to evaluate the impact of climate change on environment and human activities. They have high impact on the requirements of the Intergovernmental Panel on Climate Change (IPCC). New ECV products are now available and they can be used to characterize extreme events, such as droughts. Soil moisture is a key ECV in hydrological and agricultural processes. It constrains plant transpiration and photosynthesis (Seneviratne et al., 2010) and is one of the limiting factors of vegetation development and growth (Champagne et al., 2012), especially in water-limited regions such as the Mediterranean zone, from spring to autumn. Microwave remote sensing observations can be related to surface soil moisture (SSM) rather than to root-zone soil moisture, as the sensing depth is limited to the first centimetres of the soil surface (Wagner et al., 1999; Kerr et al., 2007). Land Surface Models (LSMs) are generally able to 
provide soil moisture simulations over multiple depths, depending upon their structure, i.e. bucket models vs. more complex vertically discretized soil water diffusion schemes (Dirmeyer et al., 1999; Georgakakos and Carpenter, 2006). Their outputs are affected by uncertainties in the atmospheric forcing, model physics and parameters. However, Rüdiger et al. (2009) showed the usefulness of using simulated SSM as a benchmark to intercompare independent satellite-derived SSM estimates, and Albergel et al. (2013a) used hindcast SSM simulations to provide an independent check on the quality of remotely sensed SSM over time. Conversely, remotely sensed SSM can be used to benchmark hindcast SSM simulations derived from two independent modelling platforms (Albergel et al., 2013b).

Leaf area index (LAI) is one of the terrestrial ECVs related to the vegetation growth and senescence. Monitoring LAI is essential for assessing the vegetation trends in the climate change context, and for developing applications in agriculture, environment, carbon fluxes and climate monitoring. LAI is expressed in $\mathrm{m}^{2} \mathrm{~m}^{-2}$ and is defined as the total one-sided area of photosynthetic tissue per unit horizontal ground area. The LAI seasonal cycle can be monitored at a global scale using medium-resolution optical satellite sensors (Myneni et al., 2002; Baret et al., 2007, 2013; Weiss et al., 2007). Another way to provide LAI over large areas and over long periods of time is to use generic LSMs, such as Interactions between Soil, Biosphere and Atmosphere, $\mathrm{CO}_{2}$-reactive (ISBA-A-gs) (Calvet et al., 1998; Gibelin et al., 2006) or ORganizing Carbon and Hydrology In Dynamic EcosystEms (ORCHIDEE) (Krinner et al., 2005).

The direct validation of climate data records, based on in situ observations, is not easy at a continental scale, as in situ observations are limited in space and time. Therefore, indirect validation plays a key role. The comparison of ECV products derived from satellite observations with ECV products derived from LSM hindcast simulations is particularly useful. Inconsistencies between two independent products permit detecting shortcomings and improving the next versions of the products.

The Mediterranean Basin will probably be affected by climate change to a large extent (Gibelin and Déqué, 2003; Planton et al., 2012). Over Europe and Mediterranean areas, the annual mean temperature of the air is likely to increase more than the global mean (IPCC assessment, 2007). In most Mediterranean regions, this trend would be associated with a decrease in annual precipitation (Christensen et al., 2007). In this context, it is important to build monitoring systems of the land surface variables over this region, able to describe extreme climatic events such as droughts and to analyse their severity with respect to past droughts.

This study was performed in the framework of the HYMEX (Hydrological cycle in the Mediterranean EXperiment) initiative (HYMEX White Book, 2008; Drobinski et al., 2009a, b, 2010), with the aim of investigating the interannual variability of LAI and SSM ECV products over the
Euro-Mediterranean area. While an attempt was made in a previous work (Szczypta et al., 2012) to simulate the hydrological droughts over the Euro-Mediterranean area, this study focuses on the monitoring of agricultural droughts and complements the joint evaluation of the ORCHIDEE and ISBAA-gs land surface model performed by Lafont et al. (2012) over France using satellite-derived LAI. A $18 \mathrm{yr}$ time period (1991-2008) is considered against an 8 yr period (20002007) in Lafont et al. (2012). Using the modelling framework implemented by Szczypta et al. (2012), we compare ISBAA-gs and ORCHIDEE simulations of LAI, and we evaluate new homogenized remotely sensed LAI and SSM data sets. The satellite-derived SSM is compared with ISBA-A-gs simulations of SSM, as ORCHIDEE has no explicit representation of this quantity. The capacity of the two models to represent the interannual variability of the vegetation growth and the impact of extreme events such as the 2003 heat wave is assessed. Finally, the synergy between SSM and LAI is investigated using the satellite products and the ISBA-A-gs model.

The data, including the leaf onset and the length of the vegetation growing period (LGP) derived from the observed and simulated LAI are first described. Then, anomalies of the detrended LAI are compared over the 1991-2008 period with a focus on the 2003 western European drought (Rebetez et al., 2006; Vidal et al., 2010). Lastly, we investigate to what extent SSM observations can be used to predict mean anomalous vegetation state conditions in the current growing season. The interannual SSM variability, resulting from satellite observations and LSM simulations, is used as an indicator able to anticipate LAI anomalies during key periods.

\section{Data and methods}

In this study, several data sets (either model simulations, atmospheric variables, or satellite-derived products) were produced or collected, over the Euro-Mediterranean area. In order to force the two LSM simulations of SSM and LAI (Sect. 2.1), the ERA-Interim surface atmospheric variables (Simmons et al., 2010) are used. The ERA-Interim data are available on a $0.5 \times 0.5^{\circ}$ grid and the LSM simulations use the same grid (Szczypta et al., 2012). The 1991-2008 $18 \mathrm{yr}$ period is considered, as in Szczypta et al. (2012). During this period, SSM products from both active (ERS-1/2, ASCAT) and passive (SSM/I, TMI, AMSR-E) microwave sensors are available and can be combined (Sect. 2.2), together with LAI products (Sect. 2.3). In order to compare the LSM simulations with the satellite products, the latter are aggregated on the same $0.5 \times 0.5^{\circ}$ grid using linear interpolation and averaging techniques. 
Table 1. Summary of the characteristics of the ORCHIDEE 1.9.5.1 tag and ISBA-A-gs SURFEXv6.2 configurations used in this study.

\begin{tabular}{|c|c|c|}
\hline Biogeophysical process & ORCHIDEE & ISBA-A-gs \\
\hline Photosynthesis & $\begin{array}{l}\text { - Farquhar et al. (1980) for C3 plants, } \\
\text { - Collatz et al. (1992) for C4 plants }\end{array}$ & $\begin{array}{l}\text { Goudriaan et al. (1985), modified by Jacobs et } \\
\text { al. (1996); same model for both C } 3 \text { and C } 4 \\
\text { plants but specific parameter values }\end{array}$ \\
\hline Main parameter of photosynthesis & Maximum carboxylation rate $(V \mathrm{c}, \max )$ & Mesophyll conductance $\left(g_{\mathrm{m}}\right)$ \\
\hline $\begin{array}{l}\text { Impact of drought on photosynthesis } \\
\text { parameters (response to root-zone soil } \\
\text { moisture) }\end{array}$ & $\begin{array}{l}\text { Linear response of } V \mathrm{c}, \max (\mathrm{McMurtrie} \text { et } \\
\text { al., 1990) }\end{array}$ & $\begin{array}{l}\text { - Log response of } g_{\mathrm{m}} \\
\text { - Linear response of the maximum saturation } \\
\text { deficit for herbaceous vegetation (Calvet, 2000) } \\
\text { - Linear response of the scaled maximum in- } \\
\text { tercellular } \mathrm{CO}_{2} \text { concentration for woody vege- } \\
\text { tation (Calvet et al., 2004) } \\
\text { - Drought-avoiding response for C3 crops, } \\
\text { needleleaf forests } \\
\text { - Drought-tolerant response for C4 crops, } \\
\text { grasslands, broadleaf forests }\end{array}$ \\
\hline Soil moisture profile & $\begin{array}{l}\text { No explicit representation of SSM; two- } \\
\text { layer soil model; the depth of the lay- } \\
\text { ers evolves through time in response to } \\
\text { "top-to-bottom" filling due to precipita- } \\
\text { tion and drying due to evapotranspiration } \\
\text { (Ducoudré et al., 1993) }\end{array}$ & $\begin{array}{l}\text { Explicit representation of SSM (0-1 cm top soil } \\
\text { layer); three-layer force-restore model (Boone } \\
\text { et al., 1999; Deardoff, 1977, 1978) }\end{array}$ \\
\hline Phenology & $\begin{array}{l}\text { - LAImax is prescribed } \\
\text { - LAImin is prognostic } \\
\text { - Growing degree days } \\
\text { (Leaf onset model was trained using satel- } \\
\text { lite NDVI data (Botta et al., 2000)) }\end{array}$ & $\begin{array}{l}\text { - LAImax is prognostic } \\
\text { - LAImin is prescribed } \\
\text { - Photosynthesis-driven plant growth and mor- } \\
\text { tality }\end{array}$ \\
\hline
\end{tabular}

\subsection{Models}

Although the generic ISBA-A-gs and ORCHIDEE LSMs share the same general structure, based on the description of the main biophysical processes, they were developed independently and differ in the way photosynthesis, transpiration, and phenology are represented. The main differences between the two models are summarized in Table 1. More details about the differences between the two models can be found in Lafont et al. (2012).

\subsubsection{ISBA-A-gs}

ISBA-A-gs is a $\mathrm{CO}_{2}$-responsive LSM (Calvet et al., 1998, 2004, 2008; Gibelin et al., 2006), simulating the diurnal cycle of carbon and water vapour fluxes, together with LAI and soil moisture evolution. The soil hydrology is represented by three layers: a skin surface layer $1 \mathrm{~cm}$ thick, a bulk root-zone reservoir, and a deep soil layer (Boone et al., 1999) contributing to evaporation through capillarity rises. Over the EuroMediterranean area, the rooting depth varies from $0.5-1.5 \mathrm{~m}$ for grasslands, to $2.0-2.5 \mathrm{~m}$ for broadleaf forests. The model includes an original representation of the impact of drought on photosynthesis (Calvet, 2000; Calvet et al., 2004). The version of the model used in this study corresponds to the "NIT" simulations performed by Szczypta et al. (2012). This version interactively calculates the leaf biomass and LAI, using a plant growth model (Calvet et al., 1998; Calvet and Soussana, 2001) driven by photosynthesis. In contrast to ORCHIDEE, no GDD-based phenology model is used in ISBAA-gs, as the vegetation growth and senescence are entirely driven by photosynthesis. The leaf biomass is supplied with the carbon assimilated by photosynthesis, and decreased by a turnover and a respiration term. Turnover is increased by a deficit in photosynthesis. The leaf onset is triggered by sufficient photosynthesis levels and a minimum LAI value is prescribed (LAImin in Table 1). The maximum annual value of LAI is prognostic, i.e. it is predicted by the model. Gibelin et al. (2006) and Brut et al. (2009) showed that ISBA-A-gs provides reasonable LAI values at regional and global scales under various environmental conditions. Calvet et al. (2012) showed that the model can be used to assess the interannual variability of fodder and cereal crops production over regions 
of France. The ISBA-A-gs LSM is embedded into the SURFEX modelling platform (Masson et al., 2013), and the simulations performed in this study correspond to SURFEX version 6.2 runs.

\subsubsection{ORCHIDEE}

ORCHIDEE (Krinner et al., 2005) is a process-based terrestrial biosphere model designed to simulate energy, water and carbon fluxes of ecosystems and is based on three submodules: (1) SECHIBA (Schématisation des Echanges Hydriques à l'Interface Biosphère-Atmosphère) is a land surface energy and water balance model (Ducoudré et al., 1993), (2) STOMATE (Saclay Toulouse Orsay Model for the Analysis of Terrestrial Ecosystems) is a land carbon cycle model (Friedlingstein et al., 1999; Ruimy et al., 1996; Botta et al., 2000), and (3) LPJ (Lund-Postdam-Jena) is a dynamic model of long-term vegetation dynamics including competition and disturbances (Sitch et al., 2003). ORCHIDEE uses a phenology model based on growing degree days (GDDs) for leaf onset. The parameters of the GDD model were calibrated by Botta et al. (2000) using remotely sensed NDVI observations. The LAI cycle simulated by ORCHIDEE is characterized by a dormancy phase, a sharp increase of LAI over a few days at the leaf onset, and a more gradual growth governed by photosynthesis, until a predefined maximum LAI value has been reached (LAImax in Table 1). Note that the prescribed LAImax is not necessarily reached in a simulation over a grid cell. The senescence phase presents an exponential decline of LAI. The leaf offset depends on leaf life span and climatic parameters. The ORCHIDEE 1.9.5.1 tag was used to perform these simulations. Only the ORCHIDEE LAI variable is used since the simple bucket soil hydrology version of this version of ORCHIDEE has no explicit representation of SSM (Table 1). An attempt was made by Rebel et al. (2012) to compare the soil moisture simulated by ORCHIDEE with the AMSR-E SSM product. They concluded that the shallow soil moisture estimates they derived from the ORCHIDEE simulations were not an explicit representation of SSM and could not be compared with the AMSR-E SSM product. Instead, they compared the AMSR-E SSM with the root-zone soil moisture simulated by ORCHIDEE, and they observed that the satellite-derived SSM had a much faster reaction time and a much shorter characteristic lag time than the simulations. This can be explained by the shallow penetration depth $(<5 \mathrm{~cm})$ of the C-band microwave signal measured by AMSR-E, which is not representative of deep soil layers.

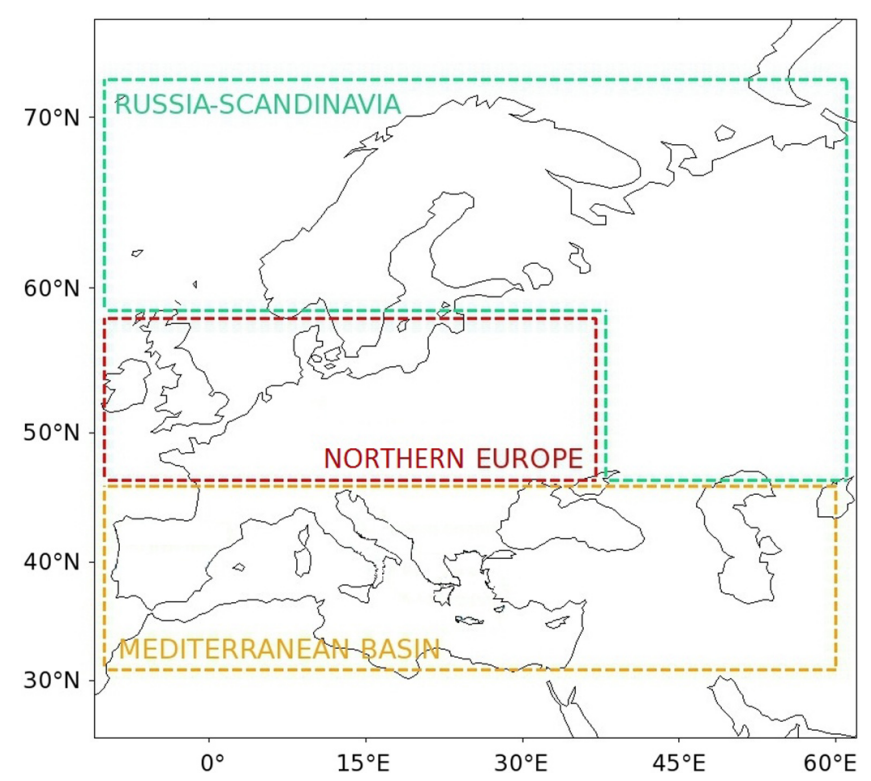

Figure 1. The Euro-Mediterranean area $\left(11^{\circ} \mathrm{W}-62^{\circ} \mathrm{E}, 25^{\circ} \mathrm{N}-\right.$ $75^{\circ} \mathrm{N}$ ) considered in this study and the three subregions: Mediterranean Basin, northern Europe, and Russia-Scandinavia.

\subsubsection{Design of the simulations}

In this study, the two models use the same spatial distribution of vegetation types, based on the ECOCLIMAP-II (Faroux et al., 2013) database of ecosystems and model parameters, over the area $11^{\circ} \mathrm{W}-62^{\circ} \mathrm{E}, 25^{\circ} \mathrm{N}-75^{\circ} \mathrm{N}$ (Fig. 1) covering the Mediterranean Basin, northern Europe, Scandinavia and part of Russia. Further, ISBA-A-gs and ORCHIDEE are driven by the same atmospheric forcing, the ERA-Interim global ECMWF atmospheric reanalysis (projected onto a $0.5^{\circ} \times 0.5^{\circ}$ grid). ERA-Interim tends to underestimate precipitation, as observed over France by Szczypta et al. (2011) and over the Euro-Mediterranean area by Szczypta et al. (2012). In the latter study, the monthly Global Precipitation Climatology Centre (GPCC) precipitation product was used to bias-correct the 3-hourly ERA-Interim precipitation estimates over the whole Euro-Mediterranean area. The resulting 3-hourly precipitation was indirectly validated using river discharges simulations and observations. The two models are driven by the 3hourly atmospheric variables from the bias-corrected ERAInterim and perform half-hourly simulations of the surface fluxes, of soil moisture and of surface temperature, together with daily LAI simulations. Irrigation is not represented. The daily LAI values are produced for each plant functional type (PFT) present in the grid cell. Similarly, daily mean SSM values are produced for each PFT. The grid-cell simulated LAI (SSM) is the average of the PFT-dependent LAI (SSM) multiplied by the fractional area of each PFT.

The model runs are performed at a spatial resolution of $0.5^{\circ} \times 0.5^{\circ}$, over the ECOCLIMAP-II Euro-Mediterranean area, corresponding to: 


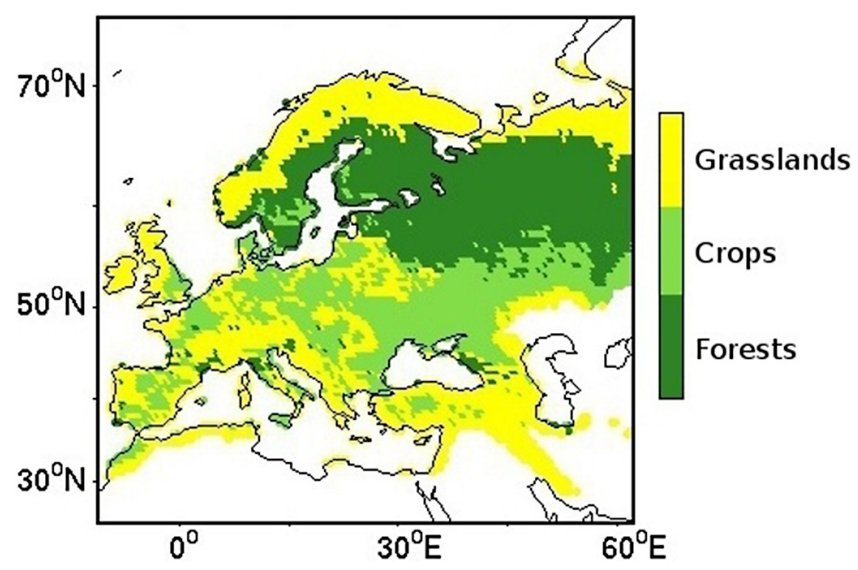

Figure 2. Dominant vegetation type (either grasslands, crops or forests) over the 8142 land grid cells $\left(0.5 \times 0.5^{\circ}\right)$ considered in this study, derived from the $1 \mathrm{~km}$ ECOCLIMAP-II data base.

- 103 ecosystem classes used to map the fractional coverage of 12 PFTs (see Figs. 7 and 9 in Faroux et al. (2013), respectively);

- 8142 land grid cells.

The fractional coverage of the various PFTs is provided by ECOCLIMAP-II at a spatial resolution of $1 \mathrm{~km}$, aggregated at a spatial resolution of $0.5^{\circ}$, and the two models account for the subgrid variability by simulating separate LAI values for each surface type present in the grid cell. ISBA-A-gs simulates separate SSM values for each surface type present in the grid cell. Figure 2 shows the spatial distribution of the dominant vegetation types over the studied domain.

\subsection{ESA-CCI surface soil moisture}

The European Space Agency Climate Change Initiative (ESA-CCI) project dedicated to soil moisture has produced a global 32-year SSM time series described in Liu et al. (2011, 2012). The ESA-CCI SSM product is today the only multidecadal SSM data set derived from satellite observations. The daily data are available on a $0.25^{\circ}$ grid and can be downloaded from http://www.esa-soilmoisture-cci.org/. Several SSM products based on either active or passive single satellite microwave sensors were combined to build a blended harmonized time series of SSM at the global scale from 1978 to 2010: scatterometer-based products from ERS1/2 and ASCAT (July 1991-May 2006 and 2007-2010, respectively), and radiometer-based products from SMMR, SSM/I, TMI, and AMSR-E (November 1978-August 1987, July 1987-2007, 1998-2008, July 2002-2010, respectively). The method used to combine the different data sets is described in detail by Liu et al. $(2011,2012)$ and takes advantage of the assets of both passive and active systems. In most of the Euro-Mediterranean area, active microwave products are used. The passive microwave products mainly cover North Africa. In some parts of the area (e.g. in Spain), the average of both active and passive microwave products is used (see Fig. 14 in Liu et al., 2012). It must be noted that the sensing depth of microwave remote sensing observations is limited to the first centimetres of the soil surface.

The ESA-CCI data set was used by Dorigo et al. (2012) to analyse trends in SSM, while Muñoz et al. (2014) and Barichivich et al. (2014) showed its strong connectivity with vegetation development. Loew et al. (2013) have assessed this product and showed that the agreement with other soil moisture data sets from modelling studies as well as with rainfall data is generally good. The ESA-CCI SSM temporal and spatial coverage is much better after 1990 than before but is limited at high latitudes due to snow cover and frozen soil conditions.

\subsection{GEOV1 LAI}

The European Copernicus Global Land Service provides a global LAI product in near-real-time called GEOV1 (Baret et al., 2013). This product was extensively validated and benchmarked with pre-existing satellite-derived LAI products using an ensemble of ground observations at 30 sites in $\mathrm{Eu}-$ rope, Africa and North America (Camacho et al., 2013). It must be noted that this direct validation does not completely address the seasonality of LAI as, for a given site, LAI observations are available at only one or very few dates. It was found that the GEOV1 LAI correlates very well with in situ observations $\left(r^{2}=0.81\right)$, with a root mean square error of $0.74 \mathrm{~m}^{2} \mathrm{~m}^{-2}$. The GEOV1 scores are better than those obtained by other products such as MODIS c5, CYCLOPES v3.1 and GLOBCARBON v2. A 32 yr LAI time series based on the GEOV1 algorithm was produced by the GEOLAND-2 project. Ten-daily data are available from 1981 to the present and can be downloaded at http://land.copernicus.eu/global/. For the period before 1999, the AVHRR Long Term Data Record (LTDR) reflectances (Vermote et al., 2009) are used to generate the LAI product at a spatial resolution of $5 \mathrm{~km}$. From 1999 onward, the SPOT-VGT reflectances are used to generate the LAI product at a spatial resolution of $1 \mathrm{~km}$. The harmonized time series is produced by neural networks trained to produce consistent estimates of LAI from the reflectance measured by different sensors (Verger et al., 2008).

\subsection{Seasonal and interannual variability}

\subsubsection{Surface soil moisture}

In this study, we focus on the seasonal and interannual variability of SSM after removing the trends from both satellitederived and simulated time series. The detrended time series at a given location and for a given 10-daily period of the year is obtained by subtracting the least-squares-fit straight line. The same 10-daily periods as for the GEOV1 LAI product 
are used. Hereafter, this quantity is referred to as SSMd, for both satellite observations and model simulations.

In order to characterize the day-to-day variability of SSMd, anomalies are calculated using Eq. (6) in Albergel et al. (2009). For each SSMd estimate at day $(j)$, a period $F$ is defined, with $F=[j-17 d, j+17 d]$. If at least five measurements are available in this period of time, the average SSMd value and the standard deviation are first calculated. Then, the scaled anomaly AnossM is computed:

$\operatorname{AnossM}(j)=\frac{\operatorname{SSMd}(j)-\overline{\operatorname{SSMd}(F)}}{\operatorname{stdev}(\operatorname{SSMd}(F))}$.

This procedure is applied to the ESA-CCI SSM observations and to the ISBA-A-gs SSM simulations.

\subsubsection{Leaf area index}

Three metrics are calculated to characterize LAI seasonal and interannual variability: the leaf onset, the leaf offset and the monthly (or 10-daily) scaled anomaly, for both satellite observations and model simulations. The LGP is defined as the period of time between the leaf onset and the leaf offset of a given annual cycle. The leaf onset (respectively, offset) is determined as the 10-daily period when the departure of LAI from its minimum annual value becomes higher (respectively, lower) than $40 \%$ of the amplitude of the annual cycle (Gibelin et al., 2006; Brut et al., 2009). This method is sufficiently robust to be applied to both deciduous and non-perennial vegetation, and to evergreen vegetation presenting a sufficiently marked annual cycle of LAI. Camacho et al. (2013) have shown that the neural network algorithm used to produce GEOV1 (Baret et al., 2013) was successful in reducing the saturation of optical signal for dense vegetation (i.e. at high LAI values). Since the saturation effect is the main obstacle to the derivation of LGP from LAI or other vegetation satellite-derived products, it can be assumed that the GEOV1-derived LGP values are reliable.

The interannual variability of LAI for various seasons is represented by monthly or 10-daily scaled anomalies defined as

$\operatorname{AnolaI}_{\mathrm{LAI}}(i, \mathrm{yr})=\frac{\operatorname{DLAI}(i, \mathrm{yr})}{\operatorname{stdev}(\operatorname{DLAI}(i,:))}$,

where $\operatorname{DLAI}(i, \mathrm{yr})$ represents the difference between LAI for a particular month ( $i$ ranging from 1 to 12 ) or 10-day period ( $i$ ranging from 1 to 36) of year (yr) and its average interannual value, and $\operatorname{stdev}(\operatorname{DLAI}(i,:))$ is the standard deviation of DLAI for a particular month or 10-day period. This procedure is applied to the GEOV1 observations and to the ORCHIDEE and ISBA-A-gs LAI simulations. In the case of GEOV1, in order to cope with shortcomings in the harmonization of satellite-derived products, the calculation of DLAI is made separately for the 1991-1998 AVHRR and for the 1999-2008 SPOT-VGT periods. It was checked that the resulting time series have a zero mean and present no trend.
Finally, the annual coefficient of variation (ACV) is computed as the ratio of the standard deviation of the mean annual LAI to the long-term mean annual LAI, over the 19912008 period. ACV characterizes the relative interannual variability of LAI.

\subsubsection{Correlation scores}

In this study, the Pearson correlation coefficient $(r)$ is used. Squared correlation coefficient $\left(r^{2}\right)$ plots are used when all the corresponding $r$ values are greater than or equal to zero. When $r$ presents negative values, $r$ is plotted instead of $r^{2}$.

\subsubsection{Leaf area index vs. surface soil moisture}

In order to assess to what extent LAI anomalies are related to the SSMd anomalies observed a few 10-day periods ahead, the Pearson correlation coefficient between 18 SSMd values (one value per year over the 1991-2008 period) and 18 DLAI values is calculated on a 10-daily basis. For each considered 10-day period, SSMd is compared to DLAI values at the same period, and to hindcast DLAI values obtained 10 days, 20 days, 30 days, 40 days and 50 days later, from March to August. Preliminary tests based on the satellitederived products showed that significant correlations were mainly obtained over cropland areas. An explanation is that LAI is more representative of the biomass production for annual crops than for managed grasslands or natural vegetation, or that natural vegetation in water-restricted areas is better adapted to changing water variability than crops. Therefore, the correlation coefficients are computed for the grid cells with more than $50 \%$ of croplands (according to the ECOCLIMAP-II land cover data). The scores are calculated with hindcast SSMd and DLAI for 10-daily time lags derived from either (1) the SSM and LAI simulated by the ISBA-A-gs LSM or (2) the ESA-CCI SSM and GEOV1 LAI products.

\section{Results}

\subsection{Modelled vs. observed SSM}

Figure 3 shows the absolute (original SSMd data) and anomaly (Anossm) correlation between the ISBA-A-gs SSM simulations and the ESA-CCI SSM product for the 19912008 period. In general, good absolute positive correlations are observed over all the sub-regions of Fig. 1. The best anomaly correlations are observed over the croplands of the Ukraine and southern Russia. However, negative correlations are observed in mountainous areas of the Mediterranean Basin, in southern Turkey (Taurus Mountains) and in western Iran (Zagros Mountains). In order to understand the negative absolute correlations in Fig. 3, we plotted (Fig. 4) the same figure as Fig. 3, except for the 2003-2008 period over which the AMSR-E product is available, using either 


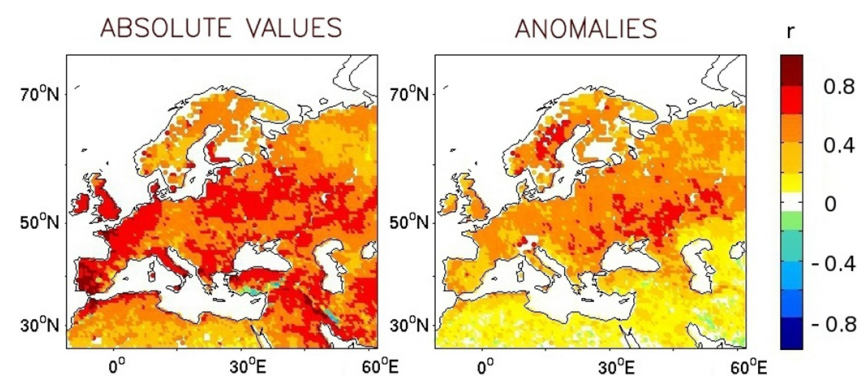

Figure 3. Comparison between the detrended ESA-CCI SSM and the detrended SSM simulated by ISBA-A-gs over the 1991-2008 period: Pearson correlation coefficient for (left) absolute values, (right) scaled anomalies (Eq. 1). White areas over land correspond to $r$ values lower (higher) than $0.1(-0.1)$.

the ESA-CCI blended (active/passive) product or the original AMSR-E product. While the results obtained with the blended product are similar to Fig. 3 over the whole domain and those obtained with AMSR-E are similar to Fig. 3 over the Mediterranean Basin, the negative correlations are not observed in the AMSR-E product. Over Northern Europe and Russia-Scandinavia, the correlations obtained for AMSR-E are lower than with the blended product. This shows that the blending technique used by Liu et al. (2012) is appropriate, apart from mountainous areas in southern Turkey and in western Iran where the active product is used, whereas the passive product is more relevant in these regions. Although the extreme 2003 year has more weight in the time series considered in Fig. 4, Fig. 3 and the top sub-figures of Fig. 4 are similar over western Europe. This shows that the consistency between ESA-CCI and ISBA-A-gs SSM is preserved during contrasting climatic conditions. Figure 5 compares the absolute and anomaly correlations $r^{2}$ of the blended product and of AMSR-E over the 2003-2008 period. Higher values are generally observed for the blended product. The AMSR-E product is more consistent with the ISBA-A-gs simulations than the blended product over $24 \%$ of the grid cells for the absolute correlations, and over $17 \%$ of the grid cells for the anomaly correlations.

\subsection{Simulated and observed phenology}

Figures 6 and 7 present leaf onset and LGP maps derived from the modelled LAI and from the GEOV1 LAI. Consistent leaf onset features (Fig. 6) are observed across satellite and model products: while the vegetation growing cycle may start at wintertime in some areas of the Mediterranean Basin (e.g. North Africa, southern Spain), the leaf onset occurs later in northern Europe (from February to July) and even later in Russia-Scandinavia (from April to August). In contrast to leaf onset, results are quite different from one data set to another for LGP (Fig. 7). In general, the two models tend to overestimate LGP. However, the LGP values produced by the photosynthesis-driven phenology model of ISBA-A-gs are

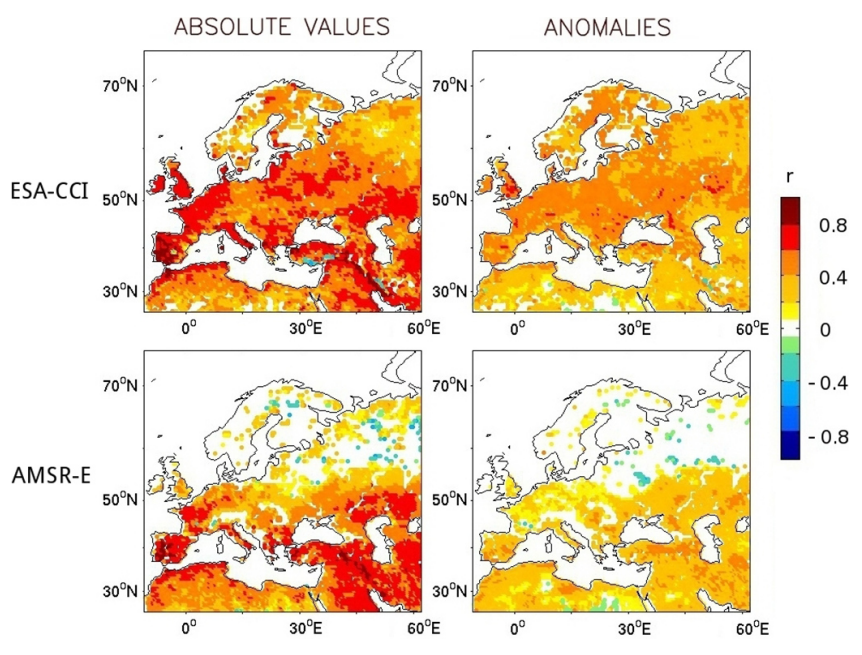

Figure 4. Same as Fig. 3, except for the 2003-2008 period and (top) ESA-CCI vs. ISBA-A-gs, (bottom) AMSR-E vs. ISBA-A-gs.
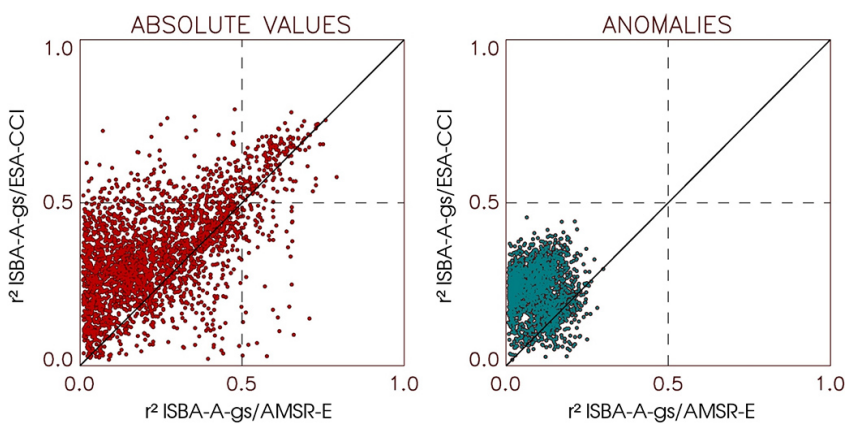

Figure 5. Detrended SSM ESA-CCI vs. AMSR-E, (left panel) absolute and (right panel) anomaly squared correlation coefficients $\left(r^{2}\right)$ with the detrended ISBA-A-gs SSM, over the 2003-2008 period. Note that $r^{2}$ values are plotted for grid cells corresponding to positive $r$ values, only.

closer to the satellite-derived LAI LGP than those produced by ORCHIDEE. On average, ORCHIDEE gives relatively high LGP values ( $180 \pm 28$ day), compared to ISBA-A-gs and GEOV1 (138 \pm 41 day and $124 \pm 44$ day, respectively). The largest LGP differences between GEOV1 and ISBA-Ags are obtained in the Iberian Peninsula and over RussiaScandinavia, where GEOV1 observes longer and shorter vegetation cycles, respectively. Figure 8 presents the differences of the two LSM simulations in leaf onset dates and LGP values (in days). It illustrates the overestimation of LGP in northern Europe by the two LSMs, and in other regions by ORCHIDEE.

Figure 9 shows the simulated and observed average annual cycle of LAI for the three regions indicated in Fig. 1. It appears clearly that GEOV1 tends to produce shorter growing seasons than the other products, apart from the Mediterranean Basin where the GEOV1 and ISBA-A-gs annual cycles of LAI are similar. In Russia-Scandinavia, the end of 


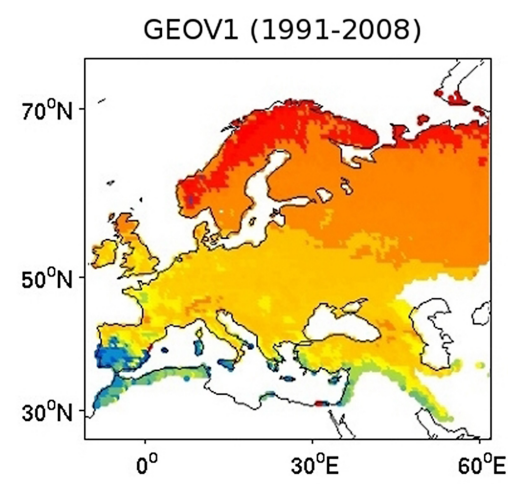

ISBA-A-gs (1991-2008)

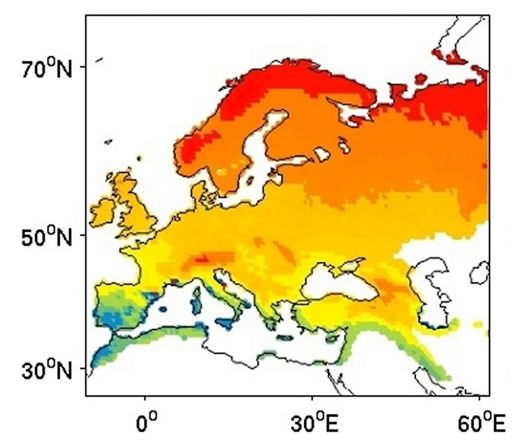

ORCHIDEE (1991-2008)

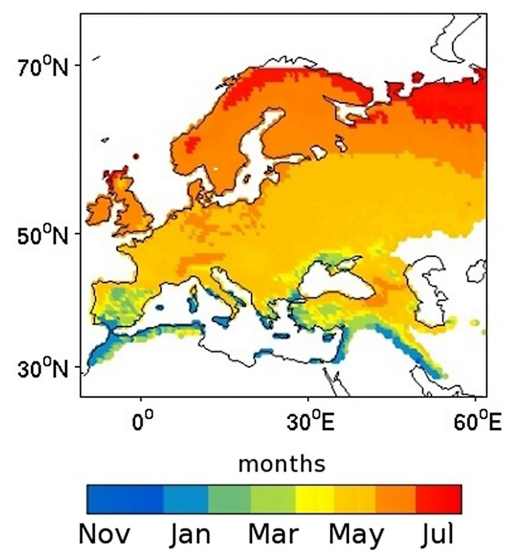

Figure 6. Mean simulated leaf onset values derived from the (top) GEOV1 LAI satellite-derived product and (middle) ISBA-A-gs LAI, and (bottom) ORCHIDEE LAI. The period used to produce the mean vegetation annual cycle is 1991-2008 for the three data sets.

the growing period in ISBA-A-gs presents a delay of about one month. This delay is not associated with a marked delay in the leaf onset (Fig. 6). This contradiction is related to the very low LAI value of ISBA-A-gs in wintertime. The prescribed minimum LAI value (LAImin in Table 1) is lower than the GEOV1 observations in wintertime and this bias has an impact on the leaf onset calculation. If LAImin was unbiased, the maximum LAI would probably be reached earlier. On the other hand, the prescribed maximum LAI value

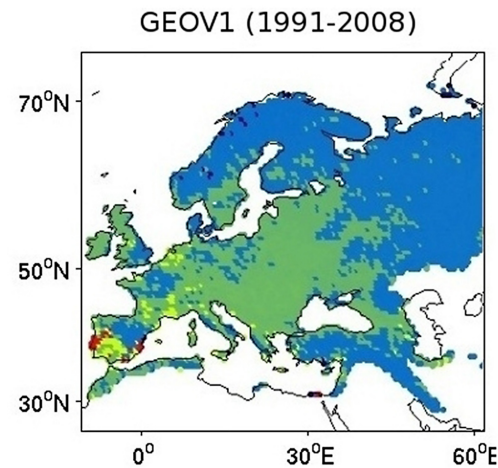

ISBA-A-gs (1991-2008)

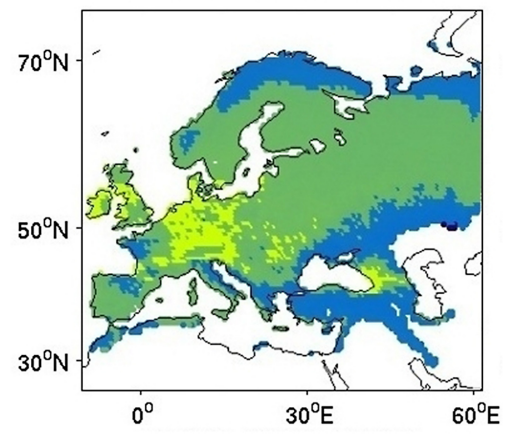

ORCHIDEE (1991-2008)

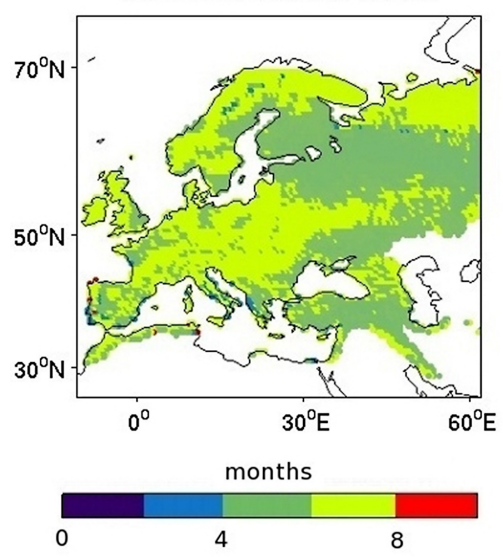

Figure 7. Same as Fig. 6, except for LGP values.

in ORCHIDEE is higher than the observations, especially in the Mediterranean Basin. On average, the prognostic LAImin of ORCHIDEE is higher than for the other products. Figure 9 shows that the ORCHIDEE delay in the leaf onset over northern Europe and Russia-Scandinavia is caused by minimum LAI values reached in March (one to two months after GEOV1) and maximum LAI values reached one month after GEOV1 (in July for northern Europe and in August for Russia-Scandinavia).

\subsection{Representation of the interannual variability of LAI}

In order to assess the interannual variability across seasons, 10-daily Ano $L A I$ values were put end to end to constitute 


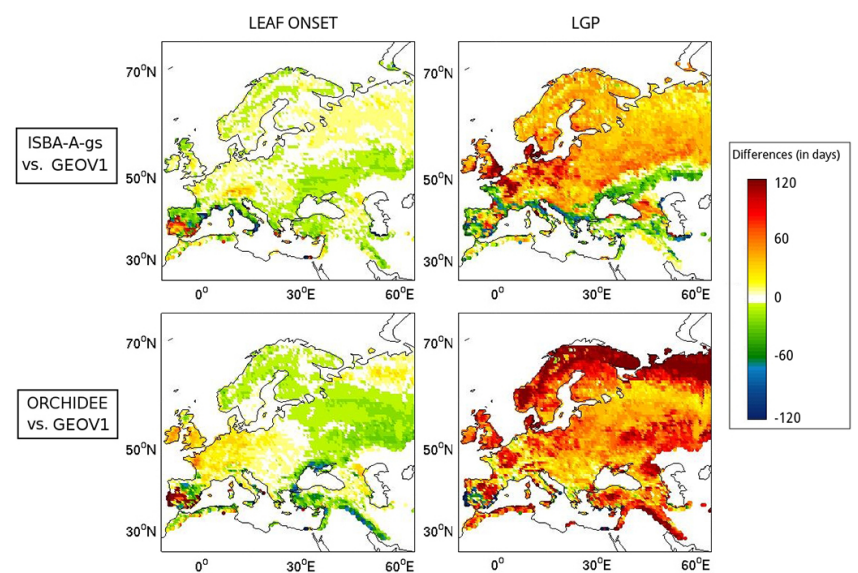

Figure 8. Mean differences in simulated (left) leaf onset values and (right) LGP of (top) ISBA-A-gs and (bottom) ORCHIDEE, over the 1991-2008 period.
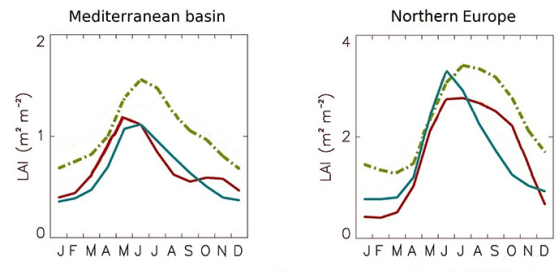

ISBA-A-gS $|A|-O P$ ORC

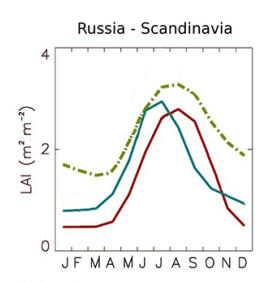

Figure 9. Mean monthly values of the ISBA-A-gs and ORCHIDEE LAI simulations, and GEOV1 LAI observations over the 19912008 period, for the three sub-regions of Fig. 1 (from left to right: Mediterranean Basin, northern Europe, and Russia-Scandinavia).

anomaly time series for each of the three LAI products (GEOV1, ISBA-A-gs, ORCHIDEE). Figure 10 presents maps of the Pearson correlation coefficient between the simulated LAI anomalies and the observed ones. Overall, ISBAA-gs is better correlated with GEOV1 than ORCHIDEE (on average, $r=0.44$ over the considered area, against $r=0.35$ for ORCHIDEE) and slightly better scores are obtained by the two models over croplands $(r=0.48$ and 0.36 , respectively). Similar results are obtained considering either median or mean $r$ values. The best correlations $(r>0.6)$ are obtained over the Iberian Peninsula, North Africa, southern Russia, and eastern Turkey. At high latitudes (northern Russia-Scandinavia), the year-to-year changes in LAI are not represented well by the two models. In these areas, the vegetation generally consists of evergreen forests presenting little seasonal and interannual variability in LAI. Moreover, up to $50 \%$ of the remotely sensed reflectances are missing, mainly due to the snow cover, clouds, high sun and view zenith angles.

Figure 11 presents the relative interannual variability of LAI, i.e. the ACV indicator defined in Sect. 2.4.2. Figure 11 shows that ACV is generally higher for ISBA-A-gs than for GEOV1, except for Scandinavia and northern Russia.
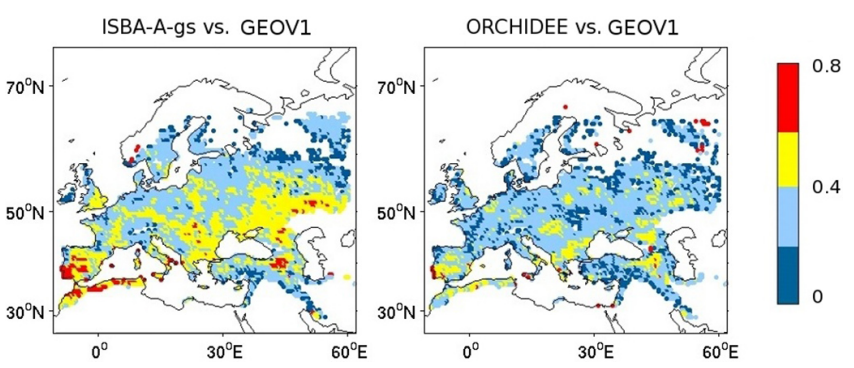

Figure 10. Pearson correlation coefficient $(r)$ between the scaled LAI 10-daily anomalies derived from detrended simulations (left, ISBA-A-gs; right, ORCHIDEE) and detrended GEOV1 satellite observations, over the 1991-2008 period, at grid cells presenting significant positive correlations ( $p$ value $<0.01$ ).

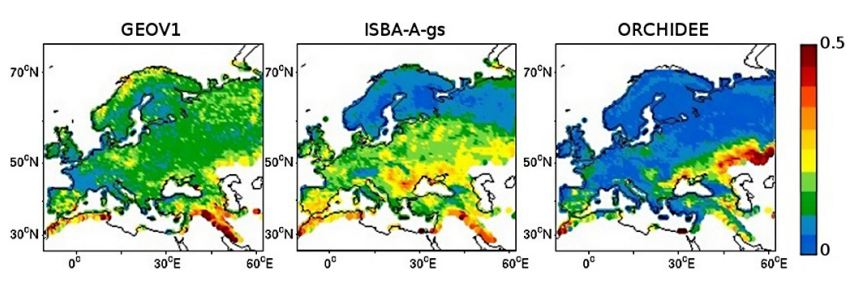

Figure 11. Annual coefficient of variation (ACV) of LAI over the 1991-2008 period (left, GEOV1; middle, ISBA-A-gs; right, ORCHIDEE).

Conversely, ACV is generally lower for ORCHIDEE than for GEOV1, except for croplands of Ukraine and southern Russia. In these areas the ORCHIDEE mean annual LAI is extremely variable (ACV values close to $50 \%$ are observed), and this variability is more pronounced than in the GEOV1 observations (ACV values are generally below $25 \%$ ).

\subsection{The 2003 drought in western Europe}

The 2003 year was marked, in Europe, by two climatic events which had a significant impact on the vegetation growth. The first one was a wintertime and springtime cold wave, which affected the growth of cereal crops in Ukraine and in southern Russia (USDA, 2003; Vetter et al., 2008). The second one was a summertime heat wave following a long spring drought, which triggered an agricultural drought over western and central Europe (Ciais et al., 2005; Reichstein et al., 2006; Vetter et al., 2008; Vidal et al., 2010). Figure 12 shows the observed and simulated monthly Ano LAI values from May to October 2003. Negative values correspond to a LAI deficit. In May and June, the impact of the cold wave in eastern Europe is clearly visible in the GEOV1 satellite observations. In the same period, the impact of the heat wave appears in western and central regions of France. At summertime, the impact of drought on LAI spreads towards southeastern France and central Europe and tends to gradually disappear in October. The LSM LAI anomalies show patterns that match the two climatic anomalies (drought in western 


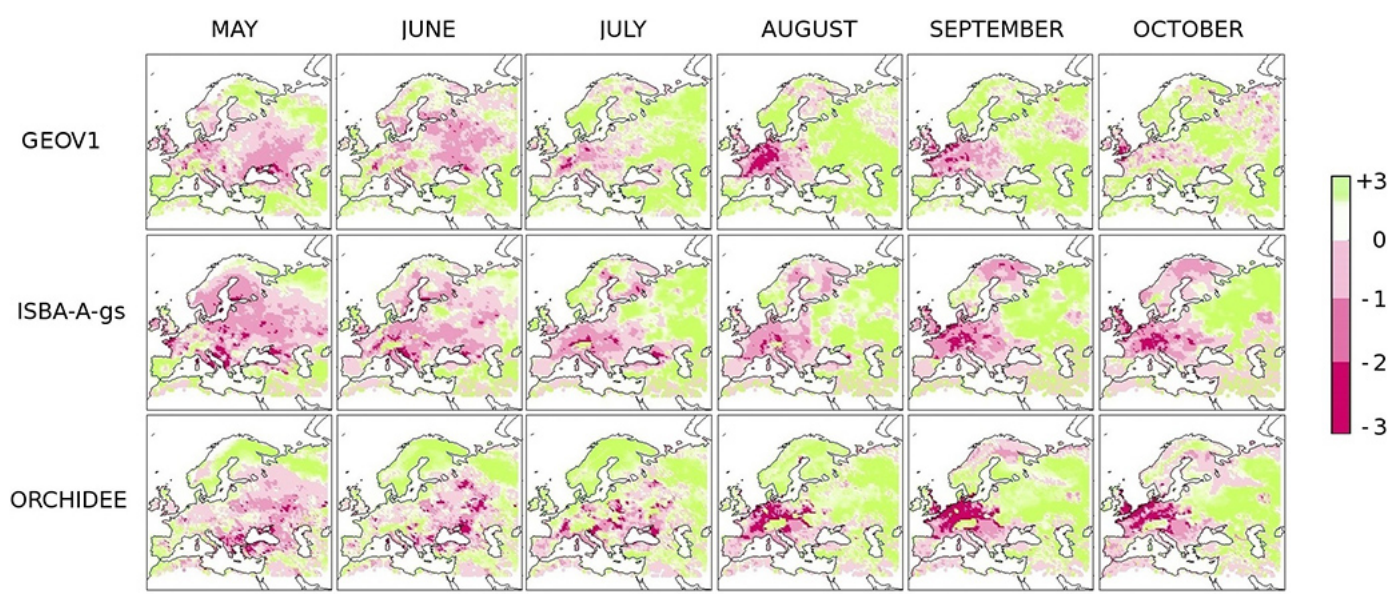

Figure 12. Scaled LAI monthly anomalies from May to October 2003. From top to bottom: GEOV1 satellite observations, detrended ISBAA-gs and ORCHIDEE simulations. Units are dimensionless and correspond to standard deviations.

and east-southern Europe; cold winter and spring in northern European Russia) but tend to maintain the agricultural drought too long in comparison to GEOV1. The Ano LAI values derived from the simulations of the two models remain markedly negative in October 2003, while the observations show that a recovery of the vegetation LAI has occurred, especially in the Mediterranean Basin area.

\subsection{Predictability of LAI anomalies}

Figure 13 presents the time lag for which the best correlation between SSMd and DLAI is obtained (see Sect. 2.4.4), for the second 10-day period of May, June and July. For a large proportion of the cropland area $(75 \%, 92 \%, 94 \%$ in May, June, July, respectively) significant correlations ( $p$ value $<0.01)$ are obtained with the model. A much lower proportion is obtained with the satellite data $(1 \%, 5 \%, 14 \%$, respectively). For the three months, the average time lag of the model ranges between 16 and 20 days, and the average time lag of satellite-derived products ranges between 18 and 34 days. In April (not shown) nearly no correlation is found with the satellite data, while $45 \%$ of the cropland area presents significant correlation for the model, with an average time lag of 34 days.

\section{Discussion}

\subsection{Representation of soil moisture}

In the two LSMs considered in this study, soil moisture impacts the LAI seasonality and interannual variability. The interannual variability of the simulated LAI is often driven by changes in the soil moisture availability, which for the soil models of the versions of ORCHIDEE and ISBA-A-gs used in this study results from rather simple parameterizations. In particular, the ability of distinct root layers to take up water and to interact with a detailed soil moisture profile is not represented. Therefore, while the difficulty in representing the modelled LAI interannual variability, as illustrated in Sects. 3.3 and 3.4, can be partly explained by shortcomings in the phenology and leaf biomass parameterizations, another factor is the inadequate simulation of root-zone soil moisture. For example, the difficulty in simulating the vegetation recovery in the Mediterranean Basin in October 2003 (Fig. 12) can be explained by shortcomings in the representation of the soil moisture profile and by the fact that Mediterranean vegetation is rather well adapted to drought with mechanisms of "emergency" stomatal closure (Reichstein et al., 2003) that prevent leaf damage and cavitation. In addition, many European tree and shrub species have deep roots and can access ground water to alleviate drought stress. The soil hydrology component of the ISBA-A-gs simulations performed in this study is based on the force-restore model. The root zone is described as a single thick soil layer with a uniform root profile. After the drought, this moisture reservoir is empty, and the first precipitation events have little impact on the bulk soil moisture stress function influencing photosynthesis and plant growth. In the real world, the high root density at the top soil layer permits a more rapid response of the vegetation growth to rainfall events. The implementation of a soil multilayer diffusion scheme in ISBA-A-gs (Boone et al., 2000; Decharme et al., 2011) is expected to improve the simulation of vegetation regrowth. Similar developments are performed in the ORCHIDEE model following de Rosnay and Polcher (1998) and d'Orgeval et al. (2008).

Moreover, LSM simulations are affected by large uncertainties in the maximum available water capacity (MaxAWC). The MaxAWC value depends on both soil (e.g. soil density, soil depth) and vegetation (e.g. rooting depth, shape of the root profile, capacity to extract water from the soil in dry conditions) characteristics. Calvet et al. (2012) showed over France that MaxAWC drives to a large extent the 


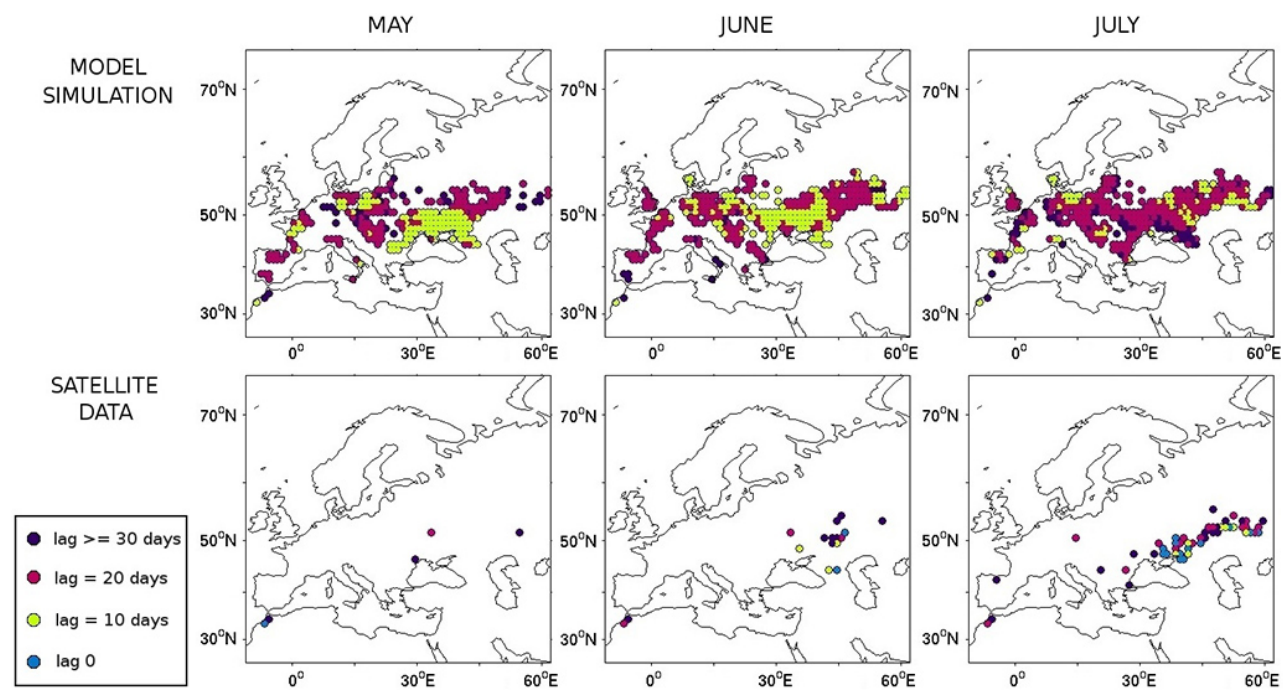

Figure 13. Predictability of LAI 10-daily differences from SSM over croplands from May to July, based on detrended (top) ISBA-Ags simulations and (bottom) satellite-derived products (GEOV1 LAI and ESA-CCI SSM). The colour dots correspond to four time lags providing the highest squared coefficient correlation $\left(r^{2}\right)$ for the predicted LAI anomaly over the 1991-2008 period. The results are given for the second 10-day period of each month at grid cells presenting significant LAI anomaly estimates $(p$ value $<0.01)$.

interannual variability of the cereal and forage biomass production simulated by ISBA-A-gs and that agricultural yield statistics can be used to retrieve these MaxAWC values. It is likely that the correlation maps of Fig. 10 could be improved by adjusting MaxAWC. In ISBA-A-gs, LAImax is a prognostic quantity related to the annual biomass production, especially for crops. Therefore, LAImax values derived from the GEOV1 LAI data could be used to retrieve MaxAWC or at least better constrain this parameter together with additional soil characteristic information and a better soil model.

\subsection{Representation of LAI}

Apart from indirectly adjusting MaxAWC (see above), the GEOV1 LAI could help improving the phenology of the two models.

In ISBA-A-gs, the LAImin parameter could be easily adapted to better match the observations before the leaf onset. In particular LAImin is mostly underestimated over grasslands (not shown). Improving the whole plant growth cycle is not easy as the ISBA-A-gs phenology is driven by photosynthesis and, therefore, depends on all the factors impacting photosynthesis, including the absorption of solar radiation by the vegetation canopy. For example, preliminary tests using a new short-wave radiative transfer within the vegetation canopy (Carrer et al., 2013) indicate that this new parameterization tends to slightly reduce the LGP value (results not shown).

Regarding ORCHIDEE, this study revealed a number of shortcomings in the phenology parameterization. The LGP values were generally overestimated (Fig. 7) and the senescence model for grasses was deficient at northern latitudes, with a much too long growing season ending at the beginning of the following year (Fig. 9). A new version is being developed, in which the phenological parameters are optimized using both in situ and satellite observations. The in situ data are derived from the FLUXNET data base (Baldocchi et al., 2008). For boreal and temperate PFTs, the leaf life span parameter is systematically reduced, leading to a shorter LGP (see e.g. Kuppel et al., 2012). A new phenological model for crop senescence involving a GDD threshold, described in Bondeau et al. (2007) and evaluated in Maignan et al. (2011), results in much shorter LGP values for crops. Finally, a temperature threshold is activated in order to improve the simulation of the senescence of grasslands.

\subsection{Can LAI anomalies be anticipated using SSM?}

The biomass accumulated at a given date is the result of past carbon uptake through photosynthesis, and in waterlimited regions it depends on past soil moisture conditions. For example, using the ISBA-A-gs model over the Puy-deDôme area in the centre of France, Calvet et al. (2012) found a very good squared correlation coefficient values $\left(r^{2}=0.64\right)$ between the simulated root-zone soil moisture in May (July) and the simulated annual cereal (managed grassland) biomass production. To some extent, SSM can be used as a proxy for soil moisture available for plant transpiration and LAI can be used as a proxy for biomass. In water-limited areas, the annual biomass production of rainfed crops and natural vegetation depends on soil moisture (among other factors) at critical periods on the year. 
The differences in predictability of LAI shown in Fig. 13 may be due to shortcomings in both observations and simulations. Significant correlations with the satellite data are only observed in homogeneous cropland plains, such as in southern Russia, especially in July. The accuracy of satellitederived LAI and SSM products is affected by heterogeneities and by topography. This may explain why the synergy between the two variables only appears in rather uniform landscapes, while the modelled variables are more easily comparable in various conditions. The ISBA-A-gs simulations present weaknesses related to the representation of the soil moisture profile (Sect. 4.1). In particular, the force-restore representation of SSM tends to enhance the coupling between SSM and the root-zone soil moisture (and hence to LAI through the plant water stress). Parrens et al. (2014) showed that the decoupling between the surface soil layers and the deepest layers in dry conditions can be simulated by using a multilayer soil model. Apart from these uncertainties, the main reason for the differences in predictability of LAI is probably that the satellite-derived LAI and SSM are completely independent while deterministic interactions between the two variables are simulated by the model.

\subsection{From benchmarking to data assimilation}

The direct validation of long time series of satellite-derived ECV products is not easy, as in situ observations are limited in space and time (Dorigo et al., 2014). Therefore, indirect validation based on the comparison with independent products (e.g. products derived from model simulations) has a key role to play (Albergel et al., 2013a). In this study, the new ESA-CCI SSM product and the new GEOV1 LAI product were compared with LSM simulations. Hindcast simulations can be used to validate satellite-derived ECV products (Sect. 3.1) and conversely, the latter can be used to detect problems in the models (Sect. 4.2). The results presented in Sect. 3.1 suggest that SSM simulations could be used to improve the blending of the active and passive microwave products. The most advanced indirect validation technique consists in integrating the products into a LSM using a data assimilation scheme. The obtained reanalysis accounts for the synergies of the various upstream products and provides statistics which can be used to monitor the quality of the assimilated observations. Barbu et al. $(2011,2014)$ have developed a Land Data Assimilation System over France (LDASFrance) using the multi-patch ISBA-A-gs LSM and a simplified extended Kalman filter. The LDAS-France assimilates GEOV1 data together with ASCAT SSM estimates and accounts for the synergies of the two upstream products. While the main objective of LDAS-France is to reduce the model uncertainties, the obtained reanalysis provides statistics which can be used to monitor the quality of the assimilated observations. The long-term LDAS statistics can be analysed in order to detect possible drifts in the quality of the products: innovations (observations vs. model forecast), residuals (observations vs. analysis) and increments (analysis vs. model forecast). This use of data assimilation techniques is facilitated by the flexibility of the vegetation-growth model of ISBA-A-gs, which is entirely photosynthesis driven.

In contrast to ISBA-A-gs, ORCHIDEE uses phenological models for leaf onset and leaf offset and the LAI cannot be easily updated with observations. Instead, a Carbon Cycle Data Assimilation System (CCDAS) can be used to retrieve model parameters (Kaminski et al., 2012; Kato et al., 2013). Using this technique, Kuppel et al. (2012) have assimilated eddy-correlation flux measurements in ORCHIDEE at 12 temperate deciduous broadleaf sites. Before the assimilation, the model systematically overestimates LGP (by up to 1 month). The model inversion produces new values of three key parameters of the phenology model and shorter LGP values are obtained.

\section{Conclusions}

For the first time, the variability in time and space of LAI and SSM derived from new harmonized satellite-derived products (GEOV1 and ESA-CCI soil moisture, respectively) was analysed over the Euro-Mediterranean area for a 18-year period (1991-2008), using detrended time series. The explicit simulation of SSM by the ISBA-A-gs LSM permitted evaluating the seasonal and the day-to-day variability of the ESACCI SSM. The comparison generally showed a good agreement between the observed and the simulated SSM, and highlighted the regions where the ESA-CCI product could be improved by revising the procedure for blending the active and passive microwave products. ORCHIDEE and ISBA-Ags were used to assess the seasonal and interannual vegetation phenology derived from GEOV1. It appeared that the GEOV1 LAI product is not affected much by saturation and was able to generate a realistic phenology. It was shown that GEOV1 can be used to detect shortcomings in the LSMs. In general, the ISBA-A-gs LAI agreed better with GEOV1 than the ORCHIDEE LAI, for a number of metrics considered in

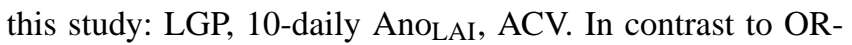
CHIDEE, the ISBA-A-gs plant phenology is entirely driven by photosynthesis and no degree-day phenology model is used. The advantage is that all the atmospheric variables influence LAI through photosynthesis. Also, the regional differences between ISBA-A-gs and the GEOV1 LAI can be handled through sequential data assimilation techniques able to integrate satellite-derived products into LSM simulations (Barbu et al., 2014). As shown in the latter study, though the main purpose of data assimilation is to improve the model simulations, the difference between the simulated and the observed LAI and SSM can be used as a metric to monitor the quality of the observed time series. On the other hand, ISBA-A-gs is very sensitive to errors in the atmospheric variables, and bias-corrected atmospheric variables must be used (Szczypta et al., 2011). 
Finally, the use of SSM to predict LAI 10 to 30 days ahead was evaluated over cropland areas. Under certain conditions, the harmonized LAI and SSM observations used in this study present consistent results over croplands, and SSM anomalies can be used to some extent to predict LAI anomalies over uniform cropland regions. The combined use of satellitederived products and models could help improve the characterization of agricultural droughts.

Acknowledgements. This work is a contribution to the GEOLAND2 research project co-funded by the European Commission within FP7 (under grant agreement No. 218795), and to the French REMEMBER project (ANR 2012 SOC\&ENV 001) within the HYMEX initiative. The work of C. Szczypta was supported by Région Midi-Pyrénées, by Météo-France, and by GEOLAND2. The contribution of W. Dorigo was supported by ESA's Climate Change Initiative for Soil Moisture (contract no. 4000104814/11/I-NB).

Edited by: H. Sato

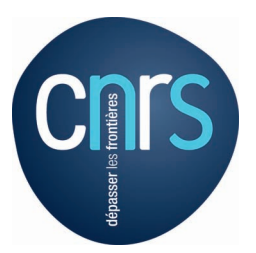

The publication of this article is financed by CNRS-INSU.

\section{References}

Albergel, C., Rüdiger, C., Carrer, D., Calvet, J.-C., Fritz, N., Naeimi, V., Bartalis, Z., and Hasenauer, S.: An evaluation of ASCAT surface soil moisture products with in-situ observations in Southwestern France, Hydrol. Earth Syst. Sci., 13, 115-124, doi:10.5194/hess-13-115-2009, 2009.

Albergel, C. Dorigo, W., Balsamo, G., Muñoz-Sabater, J., de Rosnay, P., Isaksen, L., Brocca, L., de Jeu, R., and Wagner, W.: Monitoring multi-decadal satellite earth observation of soil moisture products through land surface reanalyses, Remote Sens. Environ., 138, 77-89, doi:10.1016/j.rse.2013.07.009, $2013 \mathrm{a}$.

Albergel, C. Dorigo, W., Reichle, R. H., Balsamo, G., de Rosnay, P., Muñoz-Sabater, J., Isaksen, L., de Jeu, R., and Wagner, W.: Skill and global trend analysis of soil moisture from reanalyses and microwave remote sensing, J. Hydrometeor., 14, 1259-1277, doi:10.1175/JHM-D-12-0161.1, 2013b.

Baldocchi, D.: Breathing of the terrestrial biosphere: lessons learned from a global network of 20 carbon dioxide flux measurement system, Aust. J. Bot., 56, 1-26, 2008.

Barbu, A. L., Calvet, J.-C., Mahfouf, J.-F., Albergel, C., and Lafont, S.: Assimilation of Soil Wetness Index and Leaf Area Index into the ISBA-A-gs land surface model, grassland case study, Biogeosciences, 8, 1971-1986, doi:10.5194/bg-8-1971-2011, 2011.

Barbu, A. L., Calvet, J.-C., Mahfouf, J.-F., and Lafont, S.: Integrating ASCAT surface soil moisture and GEOV1 leaf area index into the SURFEX modelling platform: a land data assimilation application over France, Hydrol. Earth Syst. Sci., 18, 173-192, doi:10.5194/hess-18-173-2014, 2014.
Baret, F., Hagolle, O., Geiger, B., Bicheron, P., Miras, B., Huc, M., Berthelot, B., Nino, F., Weiss, M., Samain, O., Roujean, J.L., and Leroy, M.: LAI, fAPAR and fCover CYCLOPES global products derived from VEGETATION, Part 1: Principles of the algorithm, Remote Sens. Environ., 110, 275-286, 2007.

Baret, F., Weiss, M., Lacaze, R., Camacho, F., Makhmara, H., Pacholczyk, P., and Smets, B.: GEOV1: LAI and FAPAR essential climate variables and FCOVER global time series capitalizing over existing products. Part1: Principles of development and production, Remote Sens. Environ., 137, 299-309, 2013.

Barichivich, J., Briffa, K. R., Myneni, R., Van der Schrier, G., Dorigo, W., Tucker, C. J., Osborn, T. J., and Melvin, T. M.: Temperature and snow-mediated moisture controls of summer photosynthetic activity in northern terrestrial ecosystems between 1982 and 2011, Remote Sens. 2014, 6, 1390-1431, doi:10.3390/rs6021390, 2014.

Bondeau, A., Smith, P. C., Zaehle, S., Schaphoff, S., Lucht, W., Cramer, W., and Gerten, D.: Modelling the role of agriculture for the 20th century global terrestrial carbon balance, Glob. Change Biol., 13, 679-706, doi:10.1111/j.13652486.2006.01305.x, 2007.

Boone, A., Calvet, J.-C., and Noilhan, J.: Inclusion of a third soil layer in a land surface scheme using the force-restore method, J. Appl. Meteorol., 38, 1611-1630, 1999.

Boone, A., Masson, V., Meyers, T., and Noilhan J.: The influence of the inclusion of soil freezing on simulation by a soil-atmospheretransfer scheme, J. Appl. Meteorol., 9, 1544-1569, 2000.

Botta, A., Viovy, N., Ciais, P., and Friedlingstein, P.: A global prognostic scheme of leaf onset using satellite data, Glob. Change Biol., 6, 709-726, 2000.

Brut, A., Rüdiger, C., Lafont, S., Roujean, J.-L., Calvet, J.-C., Jarlan, L., Gibelin, A.-L., Albergel, C., Le Moigne, P., Soussana, J.-F., Klumpp, K., Guyon, D., Wigneron, J.-P., and Ceschia, E.: Modelling LAI at a regional scale with ISBA-A-gs: comparison with satellite-derived LAI over southwestern France, Biogeosciences, 6, 1389-1404, doi:10.5194/bg-6-1389-2009, 2009.

Calvet, J.-C.: Investigating soil and atmospheric plant water stress using physiological and micrometeorological data, Agr. Forest Meteorol., 103, 229-247, 2000.

Calvet, J.-C. and Soussana, J.-F.: Modelling $\mathrm{CO}_{2}$-enrichment effects using an interactive vegetation SVAT scheme, Agr. Forest Meteorol., 108, 129-152, 2001.

Calvet, J.-C., Noilhan, J., Roujean, J.-L., Bessemoulin, P., Cabelguenne, M., Olioso, A., and Wigneron, J.-P.: An interactive vegetation SVAT model tested against data from six contrasting sites, Agr. Forest Meteorol., 92, 73-95, 1998.

Calvet, J.-C., Rivalland, V., Picon-Cochard, C., and Guelh, J.M.: Modelling forest transpiration and $\mathrm{CO}_{2}$ fluxes-response to soil moisture stress, Agr. Forest Meteorol., 124, 143-156, doi:10.1016/j.agrformet.2004.01.007, 2004.

Calvet, J.-C., Gibelin, A.-L., Roujean, J.-L., Martin, E., Le Moigne, P., Douville, H., and Noilhan, J.: Past and future scenarios of the effect of carbon dioxide on plant growth and transpiration for three vegetation types of southwestern France, Atmos. Chem. Phys., 8, 397-406, doi:10.5194/acp-8-397-2008, 2008.

Calvet, J.-C., Lafont, S., Cloppet, E., Souverain, F., Badeau, V., and Le Bas, C.: Use of agricultural statistics to verify the interannual variability in land surface models: a case study over France with 
ISBA-A-gs, Geosci. Model Dev., 5, 37-54, doi:10.5194/gmd-537-2012, 2012.

Camacho, F., Cernicharo, J., Lacaze, R., Baret, F., and Weiss, M.: GEOV1: LAI and FAPAR essential climate variables and FCOVER global time series capitalizing over existing products. Part2: Validation and intercomparison with reference products, Remote Sens. Environ., 137, 310-329, 2013.

Carrer, D., Roujean, J.-L., Lafont, S., Calvet, J.-C., Boone, A., Decharme, B., Delire, C., Gastellu-Etchegorry, J.-P.: A canopy radiative transfer scheme with explicit FAPAR for the interactive vegetation model ISBA-A-gs: impact on carbon fluxes, J. Geophys. Res.-Biogeo., 118, 888-903, doi:10.1002/jgrg.20070, 2013.

Champagne, C., Berg, A. A., McNairn, H., Drewitt, G., and Huffman, T.: Evaluation of soil moisture extremes for agricultural productivity in the Canadian prairies, Agr. Forest Meteorol., 165, 1-11, 2012.

Christensen, J. H., Hewitson, B. Busuioc, A., Chen, A., Gao, X., Held, R., Jones, R., Kolli, R. K., Kwon, W. K., Laprise, R., Magana Rueda, V., Mearns, L., Menendez, C. G., Räisänen, J., Rinke, A., Sarr, A., Whetton, P., Arritt, R., Benestad, R., Beniston, M., Bromwich, D., Caya, D., Comiso, J., de Elia, R., and Dethloff, K.: Regional climate projections, Climate Change, 2007: The Physical Science Basis. Contribution of Working group I to the Fourth Assessment Report of the Intergovernmental Panel on Climate Change, University Press, Cambridge, Chapter 11, ISBN: 978-0-521-88009-1, 2007.

Ciais, P., Viovy, N., Reichstein, M., Ogée, J., Granier, A., Knohl, A., Rambal, S., Sanz, M.-J., Schulze, D., Chevallier, F., and Valentini, R.: An Unprecedented Reduction in Primary Productivity of Europe During the Summer Heatwave in 2003, Nature, 437, 529-533, doi:10.1038/nature03972, 2005.

Collatz, G. J., Ribas-Carbo, M., and Berry, J. A.: Coupled photosynthesis-stomatal conductance model for leaves of C4 plants, Aust. J. Plant Physiol., 19, 519-538, 1992.

Deardorff, J. W.: A parametrization of ground-surface moisture content for use in atmospheric prediction model, J. Appl. Meteorol., 16, 1182-1185, 1977.

Deardorff, J. W.: Efficient prediction of ground surface temperature and moisture with inclusion of a layer of vegetation, J. Geophys. Res., 20, 1889-1903, 1978.

Decharme, B., Boone, A., Delire, C., and Noilhan, J.: Local evaluation of the interaction between soil biosphere atmosphere soil multilayer diffusion scheme using four pedotransfer functions, J. Geophys. Res., 116, D20126, doi:10.1029/2011JD016002, 2011.

de Rosnay, P. and Polcher, J.: Modelling root water uptake in a complex land surface scheme coupled to a GCM, Hydrol. Earth Syst. Sci., 2, 239-255, doi:10.5194/hess-2-239-1998, 1998.

Dirmeyer, P. A., Dolman, A. J., and Sato, N.: The pilot phase of the global soil wetness project, B. Am. Meteorol. Soc., 80, 851-878, 1999.

Dorigo, W., de Jeu, R., Chung, D., Parinussa, R., Liu, Y., Wagner, W., and Fernandez-Prieto, D.: Evaluating global trends (19882010) in harmonized multi-satellite surface soil moisture, Geophys. Res. Lett., 39, L18405, doi:10.1029/2012GL052988, 2012.

d'Orgeval, T., Polcher, J., and de Rosnay, P.: Sensitivity of the West African hydrological cycle in ORCHIDEE to infiltration processes, Hydrol. Earth Syst. Sci., 12, 1387-1401, doi:10.5194/hess-12-1387-2008, 2008.
Dorigo, W. A., Gruber, A., De Jeu, R. A. M., Wagner, W., Stacke, T., Loew, A., Albergel, C., Brocca, L., Chung, D., Parinussa, R. M., and Kidd, R.: Evaluation of the ESA CCI soil moisture product using ground-based observations, Remote Sens. Environ., submitted, 2014.

Drobinski, P., Ducrocq, V., Lionello, P., and the HyMeX ISSC: HyMeX, a potential new CEOP RHP in the Mediterranean basin, GEWEX Newsletter, 19, 5-6, 2009a.

Drobinski, P., Béranger, K., Ducrocq, V., Allen, J. T., Chronis, G., Font, J., Madec, G., Papathanassiou, E., Pinardi, N., Sammari, C., and Taupier-Letage, I.: The HyMeX (Hydrological in the Mediterranean Experiment) program: the specific context of oceanography, MERCATOR Newsletter, 32, 3-4, $2009 \mathrm{~b}$.

Drobinski, P., Ducrocq, V., and Lionello, P.: Studying the hydrological cycle in the Mediterranean, EOS Trans. Am. geophys. Union, 91, 373, doi:10.1029/2010EO410006, 2010.

Ducoudré, N. I., Laval, K., and Perrier, A.: SECHIBA, a new set of parameterizations of the hydrologic exchanges at the landatmosphere interface within the LMD atmospheric general circulation model, J. Climate, 6, 248-273, 1993.

Faroux, S., Kaptué Tchuenté, A. T., Roujean, J.-L., Masson, V., Martin, E., and Le Moigne, P.: ECOCLIMAP-II/Europe: a twofold database of ecosystems and surface parameters at 1-km resolution based on satellite information for use in land surface, meteorological and climate models, Geosci. Model Dev., 6, 563582, doi:10.5194/gmd-6-563-2013, 2013.

Farquhar, G. D., von Caemmerer, S., and Berry, J. A.: A biochemical model of photosynthetic $\mathrm{CO}_{2}$ assimilation in leaves of $\mathrm{C} 3$ species, Planta, 149, 78-90, 1980.

Friedlingstein, P., Joel, G., Field, C. B., and Fung, I.: Toward an allocation scheme for global terrestrial carbon models, Glob. Change Biol., 5, 755-770, 1999.

Georgakakos, K. P. and Carpenter, M.: Potential value of operationally available and spatially distributed ensemble soil water estimates for agriculture, J. Hydrol., 328, 177-191, 2006.

Gibelin, A. L. and Déqué, M.: Anthropogenic climate change over the Mediterranean region simulated by a global variable resolution model, Clim. Dynam., 20, 327-339, 2003.

Gibelin, A.-L., Calvet, J.-C., Roujean, J.-L., Jarlan, L., and Los, S. O.: Ability of the land surface model ISBA-A-gs to simulate leaf area index at the global scale: Comparison with satellites products, J. Geophys. Res., 111, D18102, doi:10.1029/2005JD006691, 2006.

Goudriaan, J., van Laar, H. H., van Keulen, H., and Louwerse, W.: Photosynthesis, $\mathrm{CO}_{2}$ and plant production, in: Wheat Growth and Modelling, edited by: Day, W. and Atkin, R. K., NATO ASI Series, Plenum Press, New York, Series A, 86, 107-122, 1985.

HyMeX White Book: 123 pp., available at: http://www.hymex.org (last access: February 2014), 2008.

IPCC assessment: Climate Change 2007: Synthesis Report. Contribution of Working Groups I, II and III to the Fourth Assessment Report of the Intergovernmental Panel on Climate Change, edited by: Pachauri, R. K. and Reisinger, A., IPCC, Geneva, Switzerland, 104 pp., 2007.

Jacobs, C. M. J., Van den Hurk, B. J. J. M., and De Bruin, H. A. R.: Stomatal behaviour and photosynthetic rate of unstressed grapevines in semi-arid conditions, Agr. Forest Meteorol., 80, 111-134, 1996. 
Kaminski, T., Knorr, W., Scholze, M., Gobron, N., Pinty, B., Giering, R., and Mathieu, P.-P.: Consistent assimilation of MERIS FAPAR and atmospheric $\mathrm{CO}_{2}$ into a terrestrial vegetation model and interactive mission benefit analysis, Biogeosciences, 9, 3173-3184, doi:10.5194/bg-9-3173-2012, 2012.

Kato, T., Knorr, W., Scholze, M., Veenendaal, E., Kaminski, T., Kattge, J., and Gobron, N.: Simultaneous assimilation of satellite and eddy covariance data for improving terrestrial water and carbon simulations at a semi-arid woodland site in Botswana, Biogeosciences, 10, 789-802, doi:10.5194/bg-10-789-2013, 2013.

Kerr, Y.: Soil moisture from space: Where are we?, Hydrogeol. J., 15, 117-120, 2007.

Krinner, G., Viovy, N., de Noblet-Ducoudret, N., Ogée, J., Polcher, J., Friedlingstein, P., Ciais, P., Sitch, S., and Prentice, I.: A dynamic global vegetation model for studies of the coupled atmosphere-biosphere system, Global Biogeochem. Cy., 19, GB1015, doi:10.1029/2003GB002199, 2005.

Kuppel, S., Peylin, P., Chevallier, F., Bacour, C., Maignan, F., and Richardson, A. D.: Constraining a global ecosystem model with multi-site eddy-covariance data, Biogeosciences, 9, 3757-3776, doi:10.5194/bg-9-3757-2012, 2012.

Lafont, S., Zhao, Y., Calvet, J.-C., Peylin, P., Ciais, P., Maignan, F., and Weiss, M.: Modelling LAI, surface water and carbon fluxes at high-resolution over France: comparison of ISBA-A-gs and ORCHIDEE, Biogeosciences, 9, 439-456, doi:10.5194/bg9-439-2012, 2012.

Liu, Y. Y., Parinussa, R. M., Dorigo, W. A., De Jeu, R. A. M., Wagner, W., van Dijk, A. I. J. M., McCabe, M. F., and Evans, J. P.: Developing an improved soil moisture dataset by blending passive and active microwave satellite-based retrievals, Hydrol. Earth Syst. Sci., 15, 425-436, doi:10.5194/hess-15-425-2011, 2011.

Liu, Y. Y., Dorigo, W. A., Parinussa, R. M., de Jeu, R. A. M., Wagner, W., McCabe, M. F., Evans, J. P., and van Dijk, A. I. J. M.: Trend-preserving blending of passive and active microwave soil moisture retrievals, Remote Sens. Environ., 123, 280-297, doi:10.1016/j.rse.2012.03.014, 2012.

Loew, A., Stacke, T., Dorigo, W., de Jeu, R., and Hagemann, S.: Potential and limitations of multidecadal satellite soil moisture observations for selected climate model evaluation studies, Hydrol. Earth Syst. Sci., 17, 3523-3542, doi:10.5194/hess-17-35232013, 2013.

Maignan, F., Bréon, F. M., Chevallier, F., Viovy, N., Ciais, P., Trules, J., and Mancip, M.: Evaluation of a Global Vegetation Model using time series of satellite vegetation indices. Geosci. Model Dev., 4, 1103-1114, doi:10.5194/gmd-4-1103-2011, 2011.

Masson, V., Le Moigne, P., Martin, E., Faroux, S., Alias, A., Alkama, R., Belamari, S., Barbu, A., Boone, A., Bouyssel, F., Brousseau, P., Brun, E., Calvet, J.-C., Carrer, D., Decharme, B., Delire, C., Donier, S., Essaouini, K., Gibelin, A.-L., Giordani, H., Habets, F., Jidane, M., Kerdraon, G., Kourzeneva, E., Lafaysse, M., Lafont, S., Lebeaupin Brossier, C., Lemonsu, A., Mahfouf, J.-F., Marguinaud, P., Mokhtari, M., Morin, S., Pigeon, G., Salgado, R., Seity, Y., Taillefer, F., Tanguy, G., Tulet, P., Vincendon, B., Vionnet, V., and Voldoire, A.: The SURFEXv7.2 land and ocean surface platform for coupled or offline simulation of Earth surface variables and fluxes, Geosci. Model Dev., 6, 929-960, doi:10.5194/gmd-6-929-2013, 2013.
McMurtrie, R., Rook, D., and Kelliher, F.: Modelling the yield of pinus radiata on a site limited by water and nitrogen, For. Ecol. Manage., 30, 381-413, 1990.

Muñoz, A. A., Barichivich, J., Christie, D. A., Dorigo, W., González-Reyes, A., González, M. E., Lara, A., Sauchyn, D., and Villalba, R.: Patterns and drivers of Araucaria araucana forest growth along a biophysical gradient in the northern Patagonian Andes: linking tree rings with satellite observations of soil moisture, Austral Ecology, 39, 158-169, doi:10.1111/aec.12054, 2014.

Myneni, R. B., Hoffman, S., Knyazikhin, Y., Privette, J. L., Glassy, J., Tian, Y., Wang, Y., Song, X., Zhang, Y., Smith, G. R., Lotsch, A., Friedl, M., Morisette, J. T., Votava, P., Nemani, R. R., and Running, S. W.: Global products of vegetation leaf area and absorbed PAR from year one of MODIS data, Remote Sens. Environ., 83, 214-231, 2002.

Parrens, M., Mahfouf, J.-F., Barbu, A., and Calvet, J.-C.: Assimilation of surface soil moisture into a multilayer soil model: design and evaluation at local scale, Hydrol. Earth Syst. Sci., 18, 673689, doi:10.5194/hess-18-673-2014, 2014.

Planton, S., Lionello, P., Artale, V., Aznar, R., Carillo, A., Colin, J., Congedi, L., Dubois, C., Elizalde Arellano, A., Gualdi, S., Hertig, E., Jorda Sanchez, G., Li, L., Jucundus, J., Piani, C., Ruti, P., Sanchez-Gomez, E., Sannino, G., Sevault, F., and Somot, S.: The climate of the Mediterranean region in future climate projections, in: The Climate of the Mediterranean Region, Chapt. 8, 1st Edn., edited by: Lionello, P., Elsevier, 2012.

Rebel, K. T., de Jeu, R. A. M., Ciais P., Viovy, N., Piao, S. L., Kiely, G., and Dolman, A. J.: A global analysis of soil moisture derived from satellite observations and a land surface model, Hydrol. Earth Syst. Sci., 16, 833-847, doi:10.5194/hess-16-8332012, 2012.

Rebetez, M., Mayer, H., Dupont, O., Schindler, D., Gartner, K., Kropp, J. and, Menzel, A.: Heat and drought 2003 in Europe: a climate synthesis, Ann. For. Sci., 63, 569-577, 2006.

Reichstein, M., Tenhunen, J., Ourcival, J.-M., Rambal, S., Maglietta, F., Peressotti, A., Pecchiari, M., Tirone, G., and Valentini, R.: Inverse modeling of seasonal drought effects on canopy $\mathrm{CO}_{2} / \mathrm{H}_{2} \mathrm{O}$ exchange in three Mediterranean Ecosystems, J. Geophys. Res., 108, 4726, doi:10.1029/2003JD003430, 2003.

Reichstein, M., Ciais, P., Papale, D., Valentini, R., Running, S., Viovy, N., Cramer, W., Granier, A., Ogée, J., Allard, V., Aubinet, M., Bernhofer, C., Buchmann, N., Carrara, A., Grünwald, T., Heimann, M., Heinesch, B., Knohl, A., Kutsch, W., Loustau, D., Manca, G., Matteucci, G., Miglietta, F., Ourcival, J. M., Pilegaard, K., Pumpanen, J., Rambal, S., Schaphoff, S., Seufert, G., Soussana, J.-F., Sanz, M.-J., Vesala, T., and Zha M.: Reduction of ecosystem productivity and respiration during the European summer 2003 climate anomaly: a joint flux tower, remote sensing and modelling analysis, Glob. Change Biol., 12, 1-18, doi:10.1111/j.1365-2486.2006.01224.x, 2006.

Rüdiger, C., Calvet, J.-C., Gruhier, C., Holmes, T., De Jeu, R., and Wagner, W.: An intercomparison of ERS-Scat and AMSR-E soil moisture observations with model simulations over France, J. Hydrometeorol., 10, 431-447, doi:10.1175/2008JHM997.1, 2009.

Ruimy, A., Dedieu, G., and Saugier, B.: TURC: A diagnostic model of continental gross primary productivity and net primary productivity, Global Biogeochem. Cy., 10, 269-285, 1996. 
Seneviratne, S. I., Corti, T., Davin, E. L., Hirschi, M., Jaeger, E. B., Lehner, I., Orlowsky, B., and Teuling, A. J.: Investigating soil moisture-climate interactions in a changing climate: A review, Earth-Sci. Rev., 99, 125-161, doi:10.1016/j.earscirev.2010.02.004, 2010.

Simmons, A. J., Willett, K. M., Jones, P. D., Thorne, P. W., and Dee, D. P.: Low-frequency variations in surface atmospheric humidity, temperature, and precipitation: Inferences from reanalyses and monthly gridded observational data sets, J. Geophys. Res., 115, D01110, doi:10.1029/2009JD012442, 2010.

Sitch, S., Smith, B., Prentice, I. C., Arneth, A., Bondeau, A., Cramer,W., Kaplan, J. O., Levis, S., Lucht, W., Sykes, M. T., Thonicke, K., and Venevsky, S.: Evaluation of ecosystem dynamics, plant geography and terrestrial carbon cycling in the LPJ dynamic vegetation model, Glob. Change Biol., 9, 161-185, 2003.

Szczypta, C., Calvet, J.-C., Albergel, C., Balsamo, G., Boussetta, S., Carrer, D., Lafont, S., and Meurey, C.: Verification of the new ECMWF ERA-Interim reanalysis over France, Hydrol. Earth Syst. Sci., 15, 647-666, doi:10.5194/hess-15-647-2011, 2011.

Szczypta, C., Decharme, B., Carrer, D., Calvet, J.-C., Lafont, S., Somot, S., Faroux, S., and Martin, E.: Impact of precipitation and land biophysical variables on the simulated discharge of European and Mediterranean rivers, Hydrol. Earth Syst. Sci., 16, 3351-3370, doi:10.5194/hess-16-3351-2012, 2012.

USDA: Ukraine: Extensive damage to winter wheat, available at: http://www.fas.usda.gov/pecad2/highlights/2003/05/Ukraine_ Trip_Report/index.htm (last access: February 2014), 2003.

Verger, A., Baret, F., and Weiss, M.: Performances of neural networks for deriving LAI estimates from existing CYCLOPES and MODIS products, Remote Sens. Environ., 112, 2789-2803, 2008.
Vermote, E., Justice, C., Csiszar, I., Eidenshink, J., Myneni, R., Baret, F., Masuoka, E., Wolfe, R., and Devadiga, S.: A terrestrial surface climate data record for global change studies, Eos Trans. AGU 90(52), Fall Meet. Suppl., Abstract IN42A-08, 2009.

Vetter, M., Churkina, G., Jung, M., Reichstein, M., Zaehle, S., Bondeau, A., Chen, Y., Ciais, P., Feser, F., Freibauer, A., Geyer, R., Jones, C., Papale, D., Tenhunen, J., Tomelleri, E., Trusilova, K., Viovy, N., and Heimann, M.: Analyzing the causes and spatial pattern of the European 2003 carbon flux anomaly using seven models, Biogeosciences, 5, 561-583, doi:10.5194/bg-5561-2008, 2008.

Vidal, J.-P., Martin, E., Franchistéguy, L., Habets, F., Soubeyroux, J.-M., Blanchard, M., and Baillon, M.: Multilevel and multiscale drought reanalysis over France with the Safran-Isba-Modcou hydrometeorological suite, Hydrol. Earth Syst. Sci., 14, 459-478, doi:10.5194/hess-14-459-2010, 2010.

Wagner, W., Lemoine, G., and Rott, H.: A method for estimating soil moisture from ERS scatterometer and soil data, Remote Sens. Environ., 70, 191-207, 1999.

Weiss, M., Baret, F., Garrigues, S., and Lacaze, R.: LAI and fAPAR CYCLOPES global products derived from VEGETATION, Part 2: validation and comparison with MODIS collection 4 products, Remote Sens. Environ., 110, 317-331, doi:10.1016/j.rse.2007.03.001, 2007. 